\title{
Method for the analysis of the relationship between forest cover and streamflow in watersheds
}

\author{
Fabrina Teixeira Ferraz ${ }^{(1)}$, \\ Sidney Sara Zanetti ${ }^{(2)}$, \\ Roberto Avelino Cecílio (2), \\ Dulcinéia de Carvalho ${ }^{(1)}$, \\ Francielle Rodrigues de Oliveira ${ }^{(2)}$
}

The relationship between forest cover and streamflow of watersheds is complex and still controversial in the scientific literature. To investigate such relationship we propose an alternative method which requires the following information for each watershed: percentage of forest cover, annual rainfall, average specific streamflow ( $\left.q_{\text {ave }}\right)$, and minimum mean specific streamflow in seven consecutive days $\left(q_{7}\right)$. As a case study, we analyzed a dataset composed by 25 watersheds located in the Espírito Santo State (ESS), Brazil. We conducted simple and multiple linear regression analyses as well as partial correlation analysis between the above parameters. To reduce the effect of heterogeneity of environmental factors, watersheds with similar characteristics in term of rainfall, drainage area, and both rainfall and drainage area were grouped by cluster analysis, and the above regression and correlation analysis was repeated on each group. Our results using the whole dataset showed that forest cover has a negative relationship with watershed streamflow. The analysis of homogeneous groups of watersheds showed that the average minimum streamflow during seven days $\left(q_{7}\right)$ was more sensitive to the presence of forest cover, showing a negative relationship, especially in watersheds with low annual rainfall, while in areas with high precipitation, the annual rainfall showed a strong influence on the hydrological responses of watersheds, masking the effect of forest cover. The proposed method may be easily extended to other areas, and allows the inclusion of other relevant environmental variables according to specific cases.

Keywords: Forests, Cluster Analysis, Water Regime, Land Use, Watershed Management

growth, climate change, and land cover changes (Giri et al. 2018).

The ecological and hydrological imbalances caused by land-use changes in watersheds are widely recognized in the scientific community (Giri et al. 2018, Chaves et al. 2019, Nikolic et al. 2019, Sadeghi et al. 2019). However, the influence of forest cover on streamflow at watershed scale is still controversial, as the former has been reported to affect the latter both positively and negatively, depending on the study (Hornbeck et al. 1993, Andréassian 2004, Zhang et al. 2017, Guzha et al. 2018, Mendes et al. 2018, Schenk et al. 2020). This is due to the complexity of their relationship, of the world and it is expected to increase in the upcoming years due to population the strategies aimed to its mitigation (Wang et al. 2019), though ensuring water security is still a major global challenge. Water scarcity is prevalent in many regions
(1) Department of Forest Science, Federal University of Lavras - UFLA, 1001 Doutor Sylvio Menicucci Ave. Lavras, Minas Gerais (Brazil); (2) Federal University of Espírito Santo - UFES, 316 Governador Lindenbergue Ave. Jerônimo Monteiro, Espírito Santo (Brazil)

@ Fabrina Teixeira Ferraz (fabrina.ferraz@hotmail.com)

Received: May 28, 2020 - Accepted: May 24, 2021

Citation: Ferraz FT, Zanetti SS, Cecílio RA, de Carvalho D, de Oliveira FR (2021). Method for the analysis of the relationship between forest cover and streamflow in watersheds. iForest 14: 344-352. - doi: 10.3832/ifor3536-014 [online 2021-07-21]

Communicated by: Raffaele Lafortezza which involve many environmental variables, so that each watershed can show unique hydrological characteristics, according to local environmental conditions (Andréassian 2004).

Considering the above-mentioned uncertainties, studies that investigate the effects of forests on hydrological streamflows are necessary. So far, these studies have been generally carried out using paired experimental watersheds or long-term timetrends. Paired studies focus on two watersheds that are close and similar in terms of environmental, physical, and climatic aspects. Most of the experiments (e.g., the implementation of forest management practices) are implemented in one of the watersheds, while the other is kept as control (Brown et al. 2005). This approach is generally adopted in watersheds smaller than $100 \mathrm{~km}^{2}$ (Zhang et al. 2017). Conversely, time-trend studies are usually based on historical series data and include theories of evapotranspiration and energy balance, hydrologic modeling, or a combination of hydrographs and statistical analysis. These strategies are well-accepted for large watersheds, especially when environmental and hydrologic data are limited (Hewlett et al. 1969, Zhang et al. 2017).

A significant portion of the current knowledge on the hydrological response of 
streamflows to forest management comes from studies relying on the above consolidated methods, which have been conducted worldwide (Hornbeck et al. 1993, Zhang et al. 2001, Andréassian 2004, Brown et al. 2005, Neary 2016, Zhang et al. 2017, Awotwi et al. 2019). On the other hand, several criticisms regarding the use of these methods have been claimed in the literature. The experimental watersheds are criticized mainly for their high cost, lack of representativeness, and difficulty to transfer the results to different areas. Time-trend studies are also challenged because of the lack of a calibration period and a climate control in order to disentangle the effects of vegetation on the water balance from the effects of climate (Hewlett et al. 1969, Neary 2016).

Studies that correlate forest cover with streamflow have been conducted in monitored watersheds for several years, where hydrological data are obtained before and after the forest management (Brown et al. 2005), or through analysis of historical data sets. The main disadvantage of this approach is related to the need of monitoring forest cover, rainfall, and streamflow over several years, and to the damages caused by forest suppression. Therefore, new approaches are needed to investigate such relationships in order to provide a deeper knowledge in watershed science and support environmental stewardship.

In this study, we propose an alternative methodology based on simple statistics where neither forest suppression nor the manipulation of large volumes of historical data is required. Both rainfall and watershed size are included as influencing factors in the hydrological response. Several watersheds are used to improve regional representativeness and allow the simultaneous analysis of large areas in different regions. The low cost and easy applicability of this method can mainly benefit regions with a lack of resources to implement paired watershed experiments. Addition- ally, this approach is also beneficial to regions where the development of long-term continuous monitoring of hydrological and forestry variables is challenging.

To test the proposed methodology, we conducted our study in Southeastern Brazil, which is historically affected by strong regional differences in the volume of available water and has experienced worrying drought periods and water scarcity in recent years (Ferreira et al. 2018). According to the National Water Agency of Brazil (ANA 2017), the drought affected 48 million people in Brazil from 2013 to 2016. In 2014, the Southeastern region, which is the most populated in the country, faced the highest drought of the $21^{\text {st }}$ century, causing a water supply crisis. On the other hand, in 2018 the drought was less intense, causing an increment in the water reservoirs. However, the total rainfall after that year remained lower than expected (Cunha et al. 2019).

The unprecedented drought in Brazil may be a direct consequence of inflow depletion from the Amazon watershed, which normally brings rainfall to Midwest and Southeastern Brazil (Lawrence \& Vandecar 2015. Awange et al. 2016). Despite this, Brazil has the largest amount of fresh water on the planet (Shiklomanov 1993). These facts bring up discussions about the management of water resources and the need of a deeper knowledge on the influence of environmental variables on fresh water supply.

In this study, we focused on the relationship between streamflow and forest cover using environmental and empirical hydrological data from governmental agencies. The main goal was to test a new method to efficiently determine the correlation between forest cover and streamflow in watersheds and its application to other regions. We finally propose the adopted methodology as a viable alternative to long years of watershed monitoring data or suppression management.

\section{Material and methods}

\section{Rationale}

We used data recorded from several watersheds in one typical hydrological year. The short period of analysis is compensated by studying several watersheds at the same time under different environmental and land use conditions, which allows a better regional representation. The dataset included the following types of information: the percentage of forest cover, annual rainfall, average specific streamflow, and minimum average specific streamflow in seven consecutive days. Simple and multiple regression analysis as well as partial correlation were applied to disentangle the effect of forest cover and rainfall on watershed streamflow. To reduce the effect of heterogeneity of environmental factors, watersheds with similar characteristics in term of rainfall, drainage area, and both rainfall and drainage area were grouped by cluster analysis, and the above regression analysis was repeated on each group. A flowchart summarizing the proposed methodology is reported in Fig. 1.

\section{Data sources}

We selected 25 watersheds located in the Espírito Santo State (ESS), Southeastern Brazil (Tab. 1). According to the Köppen climate classification, the study area presents the following four major climates: Am, Aw, Cwa, and Cwb (Alvares et al. 2013). The vegetation type in the area is part of the tropical Atlantic Rainforest.

We focused on records from the streamflow and rainfall data platforms of the ESS, which were collected in the hydrological year 2007/2008 (beginning in October 2007 and ending in September 2008). This dataset was chosen since it was the most recent and complete survey of land use of the ESS (see below) and provides information from previous and subsequent years. The average annual rainfall for the selected period $(1074 \mathrm{~mm})$ was within the normal

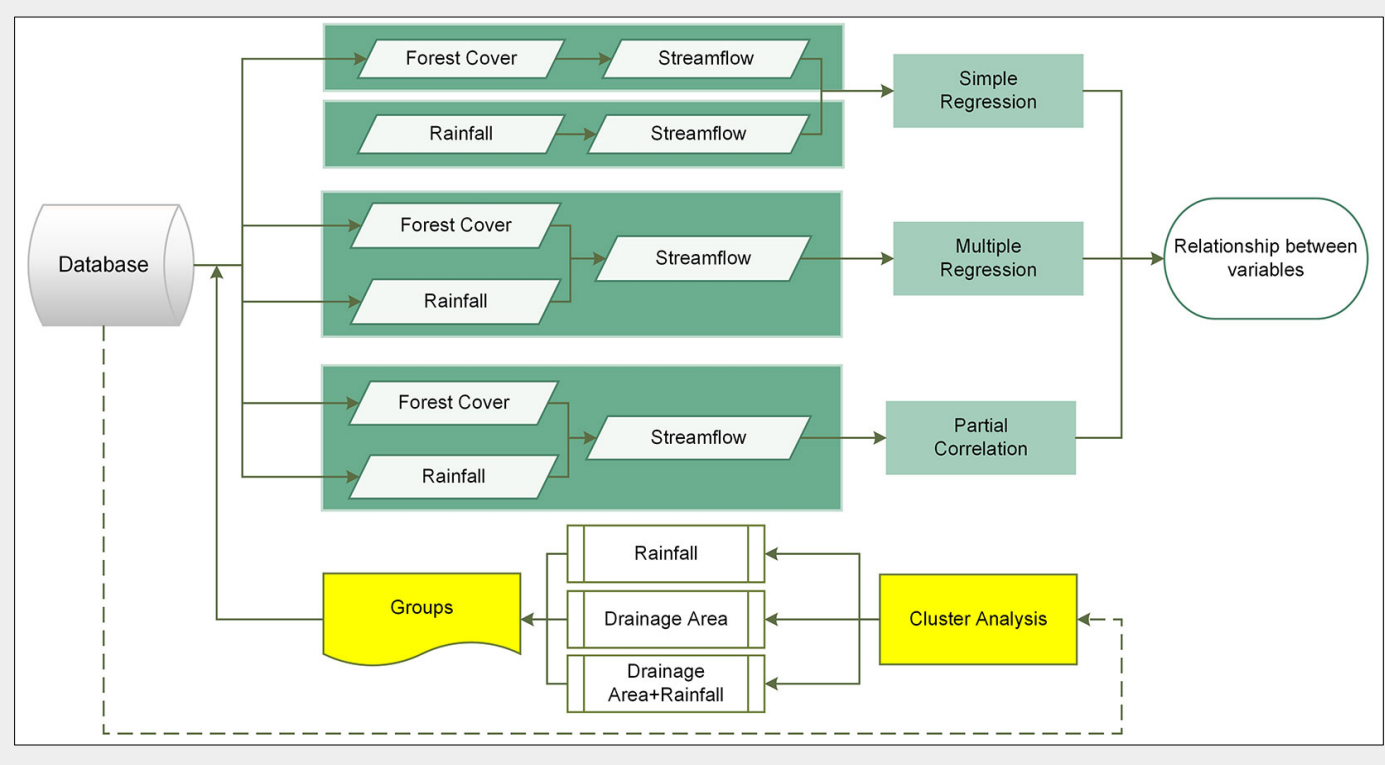

Fig. 1 - Flowchart of the proposed method. Firstly, regression and partial correlation analysis were applied on the whole data set of 25 watersheds. Cluster analysis was then performed to identify groups of watersheds with similar environmental characteristics. Finally, regression and correlation analyses were repeated separately for each group of watersheds. 
long-term range for ESS $(1186 \pm 210 \mathrm{~mm}$ year $\left.{ }^{-1}\right)$, indicating that the selected year is representative of local historical conditions. Additionally, we compared the geographical distribution and patterns of rainfall for the period 2007/2008 with the historical records to confirm its hydrological representativeness (Fig. 2).

We delimited the watersheds by referring to the upstream drainage area of each streamflow station using a HydrologicallyConsistent Digital Elevation Model (HCDEM). The HCDEM was created from the Digital Elevation Model (DEM) of SRTM (Space Shuttle Radar Topographic Mission), which was obtained from the United States Geological Survey (USGS - https:// earthexplorer.usgs.gov/) with a 30-meter resolution. Firstly, we created a mosaic of images and filled DEM sinks. To improve terrain representation, specifically regarding hydrological consistency, we reconditioned the DEM and created the HCDEM using the AGREE algorithm (Hellweger 1997), available in the Arc Hydro Tools ${ }^{\circledR}$ package of the software $\operatorname{ArcGIS}^{\circledast}$ ver. 10.3.1 (ESRI, Redwoods, CA, USA).

The watershed delimitation was obtained by successive applications of the following tools of the HCDEM in the Hydrology toolbox in ArcMap ${ }^{\oplus}$ : fill, flow direction, flow accumulation, stream definition, snap pour point, and watershed. We used the river station locations at the mouths of the main rivers as references for allocating the pour points in the snap pour point tool. Finally, the automatic delimitation of the watersheds under study was performed using the watershed tool.

\section{Water streamflow}

The streamflow data for the hydrological
Tab. 1 - Data from the watersheds under study in Espírito Santo State, Brazil. ( $q_{\text {ave }}$ ): average specific annual streamflow $\left(\mathrm{L} \mathrm{s}^{-1} \mathrm{~km}^{-2}\right) ;\left(\mathrm{q}_{7}\right)$ : minimum specific streamflow with seven days duration $\left(\mathrm{L} \mathrm{s}^{-1} \mathrm{~km}^{-2}\right)$.

\begin{tabular}{|c|c|c|c|c|c|c|}
\hline \multirow{2}{*}{ ID } & \multirow{2}{*}{ Watershed name } & \multirow{2}{*}{$\begin{array}{l}\text { Area } \\
\left(\mathrm{km}^{2}\right)\end{array}$} & \multicolumn{2}{|c|}{ Streamflow } & \multirow{2}{*}{$\begin{array}{c}\text { Rainfall } \\
(\mathrm{mm})\end{array}$} & \multirow{2}{*}{$\begin{array}{c}\text { Forest } \\
\text { cover (\%) }\end{array}$} \\
\hline & & & $q_{\text {ave }}$ & $\mathrm{q}_{7}$ & & \\
\hline 1 & Pedro Canário & 1665.9 & 3.1 & 0.3 & 690.8 & 4.7 \\
\hline 2 & São Jorge da Barra Seca & 451.7 & 4.6 & 1.0 & 820.3 & 15.7 \\
\hline 3 & Laranja da Terra & 1331.7 & 10.1 & 4.1 & 1023.2 & 23.4 \\
\hline 4 & Baixo Guandú & 2143.2 & 4.7 & 1.1 & 908.0 & 25.8 \\
\hline 5 & Córrego da Piaba & 879.4 & 3.7 & 0.2 & 818.8 & 28.5 \\
\hline 6 & Ponte do Pancas & 919.3 & 3.6 & 0.2 & 814.3 & 21.7 \\
\hline 7 & São Gabriel da Palha & 1029.4 & 8.2 & 1.2 & 848.8 & 15.7 \\
\hline 8 & Valsugana Velha - Montante & 90.3 & 13.8 & 0.5 & 1010.1 & 58.0 \\
\hline 9 & Santa Leopoldina & 1011.6 & 7.2 & 3.0 & 1042.2 & 48.5 \\
\hline 10 & Córrego do Galo & 979.0 & 10.9 & 5.0 & 1218.8 & 40.2 \\
\hline 11 & Fazenda Jucuruaba & 1688.6 & 11.5 & 5.3 & 1241.8 & 45.7 \\
\hline 12 & Matilde & 207.3 & 23.1 & 9.4 & 1480.9 & 58.2 \\
\hline 13 & Usina Fortaleza & 223.0 & 12.1 & 3.1 & 1282.6 & 24.0 \\
\hline 14 & lúna & 433.5 & 14.4 & 5.8 & 1257.8 & 11.0 \\
\hline 15 & Terra Corrida - Montante & 594.0 & 13.4 & 5.3 & 1281.2 & 12.0 \\
\hline 16 & Itaici & 1047.4 & 13.1 & 4.1 & 1303.4 & 17.1 \\
\hline 17 & Ibitirama & 341.6 & 28.1 & 5.2 & 1354.2 & 30.1 \\
\hline 18 & Rive & 2221.0 & 14.7 & 4.9 & 1355.0 & 18.5 \\
\hline 19 & Pacotuba & 2759.6 & 13.6 & 3.7 & 1358.5 & 18.2 \\
\hline 20 & Fazenda Lajinha & 436.2 & 12.4 & 2.6 & 1305.7 & 33.9 \\
\hline 21 & Castelo & 976.1 & 14.0 & 2.3 & 1364.7 & 30.3 \\
\hline 22 & Usina São Miguel & 1457.5 & 15.1 & 3.3 & 1403.1 & 31.9 \\
\hline 23 & Coutinho & 4604.4 & 14.9 & 3.7 & 1377.8 & 23.1 \\
\hline 24 & Usina Paineiras & 5169.3 & 14.2 & 3.9 & 1377.8 & 22.6 \\
\hline 25 & Guaçuí & 411.9 & 25.0 & 8.2 & 1452.5 & 22.1 \\
\hline- & Mean & 1322.9 & 12.4 & 3.6 & 1175.7 & 27.2 \\
\hline- & Standard deviation & 1272.6 & 6.3 & 2.3 & 241.2 & 13.9 \\
\hline
\end{tabular}

Fig. 2 - Geographical pattern of the rainfall in the Espírito Santo State (ESS). (Left panel): rainfall distribution in the hydrological year 2007/2008; (right panel): historical mean rainfall distribution.

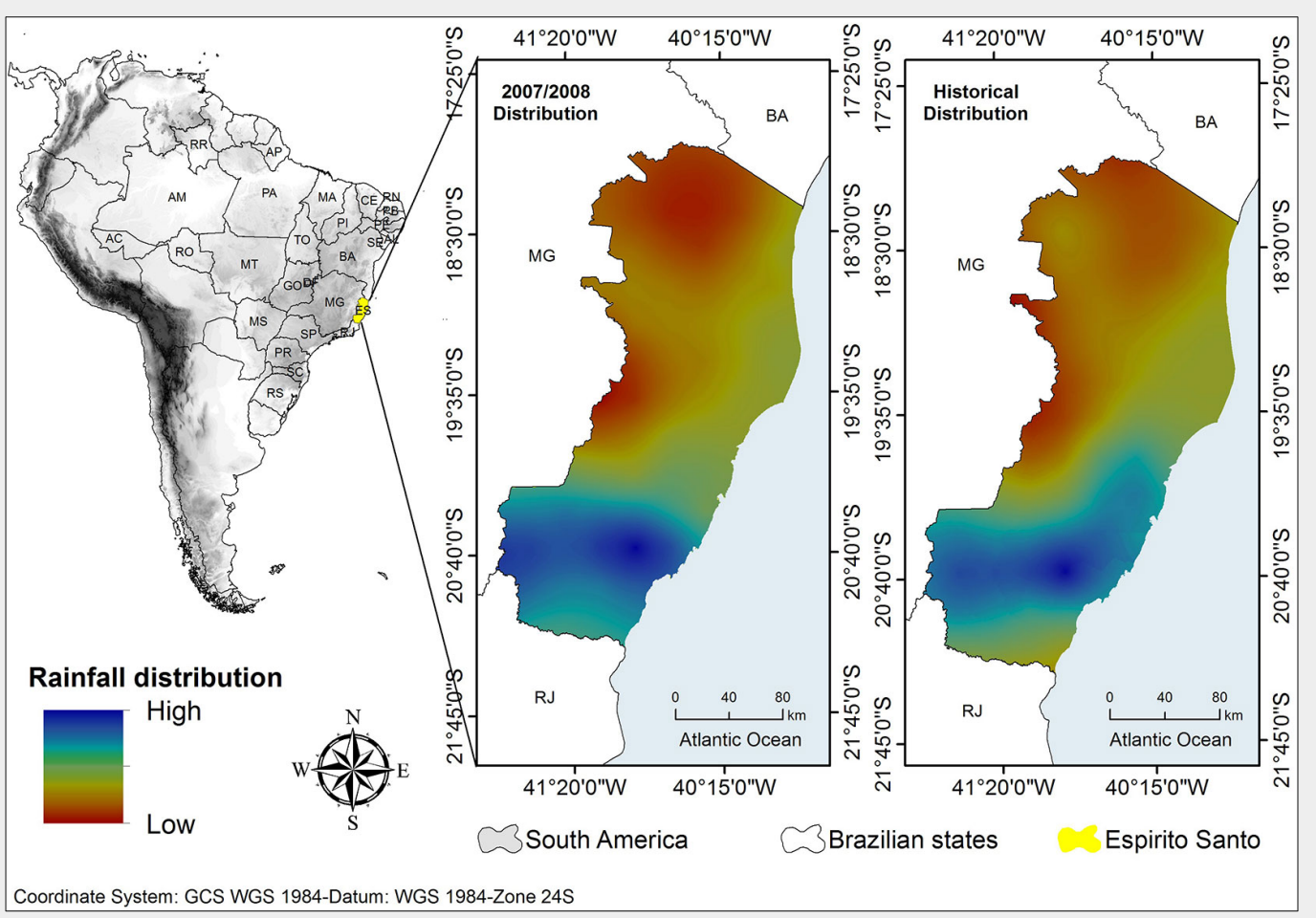


Tab. 2 - Simple linear regression between streamflow, forest cover, and rainfall for all 25 watersheds. ( $q_{\text {ave }}$ ): average specific annual streamflow $\left(\mathrm{L} \mathrm{S}^{-1}\right.$ $\left.\mathrm{km}^{-2}\right) ;\left(\mathrm{q}_{7}\right)$ : minimum specific streamflow with seven days duration ( $\left.\mathrm{L} \mathrm{s}^{-1} \mathrm{~km}^{-2}\right)$; $\left(R^{2}\right)$ : coefficient of determination.

\begin{tabular}{llcl}
\hline Variable & Stats & Rainfall & $\begin{array}{c}\text { Forest } \\
\text { cover }\end{array}$ \\
\hline \multirow{2}{*}{ qave $_{\text {and }}$} & $\mathrm{R}^{2}$ & 0.68 & 0.06 \\
\cline { 2 - 4 } & $\mathrm{p}$-value & $<0.001$ & 0.228 \\
\multirow{2}{*}{$\mathrm{q}_{7}$} & $\mathrm{R}^{2}$ & 0.61 & 0.04 \\
\cline { 2 - 4 } & $\mathrm{p}$-value & $<0.001$ & 0.346 \\
\hline
\end{tabular}

Tab. 3 - Multiple linear regression and partial correlation between streamflow, forest cover, and rainfall for all 25 watersheds; $\left(q_{a v e}\right)$ : average specific annual streamflow $\left(\mathrm{L} \mathrm{s}^{-1} \mathrm{~km}^{-2}\right) ;\left(\mathrm{q}_{7}\right)$ : minimum specific streamflow with seven days duration ( $\left.\mathrm{L} \mathrm{s}^{-1} \mathrm{~km}^{-2}\right)$; $\left(\mathrm{r}_{\mathrm{p}}\right)$ : coefficient of partial correlation; $\left(R^{2}\right)$ : coefficient of determination.

\begin{tabular}{llll}
\hline Variable & Stats & Rainfall & $\begin{array}{c}\text { Forest } \\
\text { cover }\end{array}$ \\
\hline \multirow{4}{*}{$q_{\text {ave }}$} & $\mathrm{R}^{2}$ & \multicolumn{2}{c}{0.69} \\
\cline { 2 - 4 } & $\mathrm{p}$-value & \multicolumn{2}{c}{$<0.001$} \\
\cline { 2 - 4 } & $\mathrm{r}_{\mathrm{p}}$ & 0.82 & 0.14 \\
\cline { 2 - 4 } & $\mathrm{p}$-value & $<0.001$ & 0.516 \\
$\mathrm{q}_{7}$ & $\mathrm{R}^{2}$ & \multicolumn{2}{c}{0.61} \\
\hline & $\mathrm{p}$-value & \multicolumn{2}{c}{$<0.001$} \\
\hline & $\mathrm{r}_{\mathrm{p}}$ & 0.77 & 0.06 \\
\cline { 2 - 4 } & $\mathrm{p}$-value & $<0.001$ & 0.8 \\
\hline
\end{tabular}

year 2007/2008 was obtained from streamflow stations of the ESS, which are freely available at the National Information Sys tem on Water Resources (Sistema Nacional de Informações Sobre Recursos Hídricos, SNIRH - http://www.snirh.gov.br/hidro web). For some of the stations pre-processed data were not available, and raw data was considered. In the pre-processing step, we filled the gaps using simple linear regression between streamflows and the station elevations. The stations with a gap rate above $3 \%$ were disregarded since they presented atypical values according to the tendency of the hydrographs. After preprocessing, 25 streamflow stations were selected for further analyses.

The average annual streamflow rate $\left(Q_{\text {ave }}\right)$ and the average minimum streamflow rate for seven days $\left(\mathrm{Q}_{7}\right)$ for the hydrological year 2007/2008 were obtained for each station. We also estimated the respective specific streamflows ( $q_{\text {ave }}$ and $q_{7}$ ), which are calculated as the ratio between the streamflow (Q) and the drainage area $\left(\mathrm{km}^{2}\right)$ of each watershed.

Rainfall

Daily rainfall data was obtained from the daily gridded meteorological variables in Brazil (https://utexas.app.box.com/v/Xavie r-etal-IJOC-DATA - Xavier et al. 2016), which consists of a grid dataset $\left(0.25^{\circ} \times\right.$ $0.25^{\circ}$ ) spatially interpolated from station rainfall data. Total annual rainfall for the hydrological year 2007/2008 was obtained for each grid point covering the ESS. To obtain the annual rainfall for each watershed with a spatial resolution of $30 \mathrm{~m}$, we interpolated this variable over the entire state using the ordinary kriging (linear model) in ArcGIS ver. 10.3.1 (Silva et al. 2011).

\section{Forest cover}

Forest cover data for the years 2007 and 2008 were obtained from the aerophotogrammetric land use survey carried out by the Instituto Estadual do Meio Ambiente e Recursos Hídricos (IEMA), which is freely available at the GEOBASES data portal (https://geobases.es.gov.br/links-para-map es1215). Additionally, we used an orthophotomosaic with 1-m spatial resolution representing the most recent complete survey of the vegetation of the ESS. Among the 25 classes present in the original survey, we selected only the areas of interest, which included the classes "Native Forest" and "Native Forest in Initial Regeneration Stage". To estimate the forest cover, the previously delimited watersheds were used as a mask and forest cover was calculated for each watershed. The classes of silvicultural crops composed of exotic species, such as eucalypts, rubber, and pine trees, were excluded from the analysis as their ecological systems differ substantially from native forests. However, according to the orthophotomosaic, the silvicultural crop areas were negligible during 2007 and 2008, and no streamflow stations were present in most of these sites, making it impossible to establish any relationship between forest cover and streamflow.

\section{Statistical analyses}

The relationships of the percentage of forest cover and the rainfall with the average specific annual streamflow ( $q_{a v e}$ ) and the minimum specific streamflow with seven days duration $\left(q_{7}\right)$ were estimated using simple and multiple linear regression. Also, a partial correlation between forest cover and streamflow was applied using the rainfall as a fixed effect. The analyses were performed using together all the 25 watersheds, and the significance of the results was assessed by the F-test with $a=$ 0.10 .

As watersheds naturally presented different sizes, the contrasting rainfall regimes may influence their hydrological behavior. Thus, the linear regression and the partial correlation were applied separately after grouping the watersheds by similarity. Three different approaches of watershed grouping were adopted according to: (a) homogeneous regions of rainfall; (b) drainage area; and (c) both rainfall and drainage area. We used the hierarchical cluster analysis along with Ward's method (Ward 1963) based on the average Euclidean distance as a measure of similarity between watersheds.

\section{Results and discussion}

\section{Joint analysis of the watersheds}

The results obtained from the data of all 25 watersheds are presented in Tab. 2 and Tab. 3. As expected, we found a significant relationship between rainfall and streamflow. According to the partial correlation coefficients, higher streamflow rates are associated with higher rainfall rates in the watersheds. This is in agreement with previous studies (Tu et al. 2004, Mendes et al. 2018, Zabaleta et al. 2018), and confirms that rainfall acts as the main input component of water in the hydrological cycle, boosting the other stages of the cycle and the flows of water bodies.

The relationship between streamflow and forest cover using the whole dataset of 25 watershed was not significant (Tab. 2, Tab. 3). However, Zabaleta et al. (2018) report that in some cases the strong influence of rainfall on hydrological responses of watersheds may mask the relationship between streamflow and land cover in areas with rainfall gradients, such as those considered in this study. Indeed, the heterogeneity of the studied watersheds may have masked the relationship between streamflow and forest cover. Therefore, we investigated this relationship using more homogeneous watershed groups from the cluster analysis.

\section{Watershed grouping}

Cluster analysis based on rainfall similarity allowed to detect four groups of watersheds, considering the assumed cut point (Fig. 3). The group composed of Santa Leopoldina, Laranja da Terra, and Valsugana Velha watersheds was discarded, as it was formed by only three members and thus was deemed insufficient to perform the statistical analyses. The remaining three watershed groups $\left(P_{1}, P_{2}\right.$, and $P_{3}$.) were organized following a decreasing order of average rainfall (Fig. 3a). Group $\mathrm{P}_{1}$ included watersheds with the highest average rainfall $(1391.6 \pm 45.8 \mathrm{~mm})$, group $\mathrm{P}_{2}$ had an intermediate average rainfall $(1270.2 \pm 32.2 \mathrm{~mm})$, and group $\mathrm{P}_{3}$ had the lowest average rainfall $(816.9 \pm 71.0 \mathrm{~mm})$.

Cluster analysis of watersheds based on their drainage area resulted in four groups (Fig. 3b). The group formed by the Coutinho and Usina Paineiras watersheds (the largest of the data set) was discarded due to the insufficient number of watersheds. The remaining three groups ( $A_{1}, A_{2}$, and $A_{3}$ ) were organized according to their mean area (Fig. 3b): group A1 (average size of $1895.4 \pm 503.2 \mathrm{~km}^{2}$ ); group A2 (average size of $\left.977.5 \pm 60.2 \mathrm{~km}^{2}\right)$; and group $\mathrm{A}_{3}$ (average size of $354.4 \pm 154.9 \mathrm{~km}^{2}$ ).

Finally, the cluster analysis carried out according to both drainage areas and rainfall 
Fig. 3 - Dendrograms obtained by cluster analysis of watersheds with similar environmental characteristics, according to: (a) rainfall; (b) drainage area; and $(\mathrm{c})$ both drainage area and rainfall.

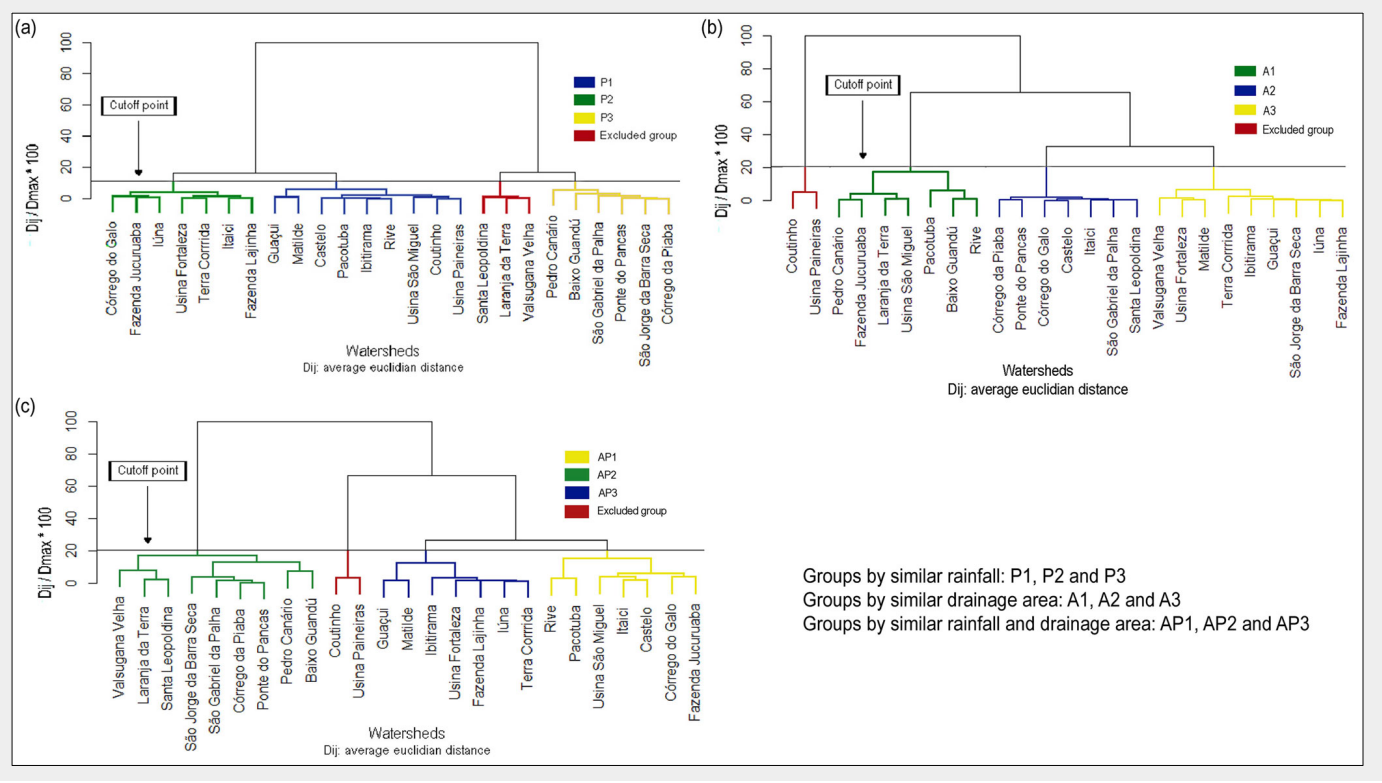

allowed to detect four groups of watersheds. The group formed by the Coutinho and Usina Paineiras watersheds was discarded due to the insufficient number of watersheds. The remaining three groups $\left(A P_{1}, A P_{2}\right.$, and $\left.A P_{3}\right)$ were as follows (Fig. $3 \mathrm{C})$ : the group $A P_{1}$ included the watersheds with the largest areas $\left(1589.9 \pm 687.8 \mathrm{~km}^{2}\right)$ and medium/high rainfall rates (1320.8 \pm $68.6 \mathrm{~mm}$ ); the group $\mathrm{AP}_{2}$ included the medium-sized watersheds $(1058.0 \pm 610.3$ $\left.\mathrm{km}^{2}\right)$ and lower rainfall rates $(886.3 \pm 118.6$ $\mathrm{mm})$; and the group $\mathrm{AP}_{3}$ included the smallest watersheds $\left(378.2 \pm 134.6 \mathrm{~km}^{2}\right)$ with the highest average rainfall $(1345.0 \pm 88.7$ $\mathrm{mm})$.

\section{Analysis by groups of homogeneous watersheds}

Tab. 4 and Tab. 5 show the simple linear regression analysis, the multiple linear regression analysis, and the partial correlation between streamflow, forest cover, and rainfall for each cluster of watersheds formed as a function of rainfall, drainage area, and drainage area and rainfall simultaneously. As already observed for the joint analysis (see above), the annual rainfall predominantly affects the watershed streamflow (Tab. 4, Tab. 5). In general, there were no significant effects of rainfall for the cluster of watersheds according to similar rainfall rates $\left(P_{1}, P_{2}\right.$, and $P_{3}$ groups), due to the reduction of the data variance within the groups which lowered the statistical power of the applied test.

A significant association between minimum streamflow and rainfall $(p$-value $=$ 0.036) was found for group $P_{2}$, which included the watersheds with intermediate precipitation, with a negative tendency $\left(r_{p}\right.$ $=-0.84)$. This means that an increase in rainfall imply a reduction in the streamflow, thus contrasting the physical processes of inflow and outflow of water in the watershed. However, the environmental heterogeneity of the region, which is composed of coastal to mountainous areas, may have a great influence on local evapotranspiration, infiltration, and water storage rates due to the presence of other environmental factors not analyzed in this work, such as geological or pedological aspects. Moreover, in some cases, environmental factors may not directly explain changes in the streamflow regime but may be an effect of anthropogenic influences (Santos et al. 2010). Therefore, the region that comprises the watersheds Córrego do Galo, Fazenda Jucuruaba, lúna, Fortaleza, Terra Corrida, Itaici, and Fazenda Lajinha

requires further research regarding, e.g., soil hydraulic properties to better understand the factors influencing water availability in those watercourses.

Regarding the influence of forest cover in the first group by rainfall $\left(P_{1}, P_{2}\right.$, and $\left.P_{3}\right)$, we found a significant relationship with average and minimum streamflows (Tab. 4, Tab. 5). In both cases, the relationship showed a negative tendency $\left(r_{p}-\right.$ Tab. 5), which means that lower streamflows occurred in watersheds with a higher forest cover and vice-versa. Furthermore, we observed that the minimum streamflows $\left(\mathrm{q}_{7}\right)$

Tab. 4 - Simple linear regression between streamflow, forest cover, and rainfall for the watershed groups obtained by cluster analysis. $\left(\mathrm{q}_{\mathrm{ave}}\right)$ : average specific annual streamflow $\left(\mathrm{L} \mathrm{s}^{-1} \mathrm{~km}^{-2}\right) ;\left(\mathrm{q}_{7}\right)$ : minimum specific streamflow with seven days duration ( $\mathrm{L}$ $\left.\mathrm{s}^{-1} \mathrm{~km}^{-2}\right)$; $\left(\mathrm{R}^{2}\right)$ : coefficient of determination.

\begin{tabular}{|c|c|c|c|c|c|c|}
\hline \multirow{2}{*}{$\begin{array}{c}\text { Cluster } \\
\text { Analysis }\end{array}$} & \multirow{2}{*}{$\begin{array}{l}\text { Watershed } \\
\text { groups }\end{array}$} & \multirow{2}{*}{ Variables } & \multicolumn{2}{|c|}{ Streamflow $q_{\text {ave }}$} & \multicolumn{2}{|c|}{ Streamflow $q_{7}$} \\
\hline & & & $\mathbf{R}^{2}$ & p-value & $\mathbf{R}^{2}$ & $\mathrm{p}$-value \\
\hline \multirow{6}{*}{ 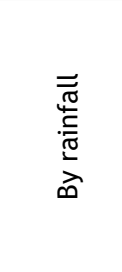 } & \multirow{2}{*}{$\mathrm{P}_{1}$} & Rainfall & 0.21 & 0.218 & 0.68 & 0.006 \\
\hline & & Forest & 0.16 & 0.285 & 0.30 & 0.126 \\
\hline & \multirow{2}{*}{$\mathrm{P}_{2}$} & Rainfall & 0.22 & 0.285 & 0.41 & 0.120 \\
\hline & & Forest & 0.82 & 0.005 & 0.03 & 0.710 \\
\hline & \multirow{2}{*}{$P_{3}$} & Rainfall & 0.23 & 0.333 & 0.37 & 0.202 \\
\hline & & Forest & 0.00 & 0.981 & 0.00 & 0.971 \\
\hline \multirow{6}{*}{ 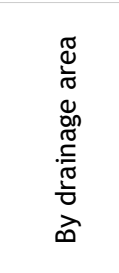 } & \multirow{2}{*}{$A_{1}$} & Rainfall & 0.95 & $<0.001$ & 0.62 & 0.037 \\
\hline & & Forest & 0.17 & 0.365 & 0.36 & 0.155 \\
\hline & \multirow{2}{*}{$\mathrm{A}_{2}$} & Rainfall & 0.88 & 0.002 & 0.64 & 0.032 \\
\hline & & Forest & 0.00 & 0.986 & 0.15 & 0.390 \\
\hline & \multirow{2}{*}{$\mathrm{A}_{3}$} & Rainfall & 0.60 & 0.014 & 0.71 & 0.004 \\
\hline & & Forest & 0.09 & 0.437 & 0.00 & 0.962 \\
\hline \multirow{6}{*}{ 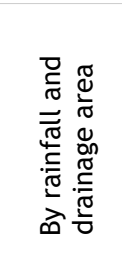 } & \multirow{2}{*}{$\mathrm{AP}_{1}$} & Rainfall & 0.94 & $<0.001$ & 0.52 & 0.069 \\
\hline & & Forest & 0.39 & 0.136 & 0.09 & 0.525 \\
\hline & \multirow{2}{*}{$\mathrm{AP}_{2}$} & Rainfall & 0.57 & 0.018 & 0.50 & 0.033 \\
\hline & & Forest & 0.45 & 0.049 & 0.03 & 0.637 \\
\hline & \multirow{2}{*}{$\mathrm{AP}_{3}$} & Rainfall & 0.57 & 0.048 & 0.65 & 0.028 \\
\hline & & Forest & 0.16 & 0.376 & 0.14 & 0.400 \\
\hline
\end{tabular}


Tab. 5 - Multiple linear regression and partial correlation between streamflow, forest cover, and rainfall for the watershed groups obtained by cluster analysis. ( $\left.\mathrm{q}_{\text {ave }}\right)$ : average specific annual streamflow $\left(\mathrm{L} \mathrm{s}^{-1} \mathrm{~km}^{-2}\right) ;\left(\mathrm{q}_{7}\right)$ : minimum specific streamflow with seven days duration $\left(\mathrm{L} \mathrm{s}^{-1} \mathrm{~km}^{-2}\right)$; $\left(\mathrm{R}^{2}\right)$ : coefficient of determination; $\left(r_{\mathrm{p}}\right)$ : coefficient of partial correlation.

\begin{tabular}{|c|c|c|c|c|c|c|c|c|c|c|}
\hline \multirow{2}{*}{$\begin{array}{l}\text { Cluster } \\
\text { Analysis }\end{array}$} & \multirow{2}{*}{$\begin{array}{l}\text { Watershed } \\
\text { groups }\end{array}$} & \multirow{2}{*}{ Variables } & \multicolumn{4}{|c|}{ Streamflow qave } & \multicolumn{4}{|c|}{ Streamflow $\mathrm{q}_{7}$} \\
\hline & & & $\mathbf{R}^{2}$ & $\mathrm{p}$-value & $r_{p}$ & $\mathrm{p}$-value & $\mathbf{R}^{2}$ & $\mathrm{p}$-value & $r_{p}$ & $\mathrm{p}$-value \\
\hline \multirow{6}{*}{ 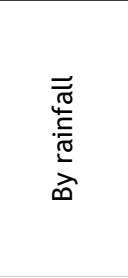 } & \multirow{2}{*}{$\mathrm{P}_{1}$} & Rainfall & \multirow{2}{*}{0.22} & \multirow{2}{*}{0.469} & 0.27 & 0.512 & \multirow{2}{*}{0.68} & \multirow{2}{*}{0.032} & 0.74 & 0.036 \\
\hline & & Forest & & & 0.14 & 0.740 & & & -0.03 & 0.949 \\
\hline & \multirow{2}{*}{$\mathrm{P}_{2}$} & Rainfall & \multirow{2}{*}{0.82} & \multirow{2}{*}{0.032} & 0.10 & 0.858 & \multirow{2}{*}{0.72} & \multirow{2}{*}{5.047} & -0.84 & 0.036 \\
\hline & & Forest & & & -0.88 & 0.022 & & & -0.72 & 0.107 \\
\hline & \multirow{2}{*}{$\mathrm{P}_{3}$} & Rainfall & \multirow{2}{*}{0.57} & \multirow{2}{*}{0.284} & 0.75 & 0.141 & \multirow{2}{*}{0.91} & \multirow{2}{*}{0.028} & 0.95 & 0.012 \\
\hline & & Forest & & & -0.66 & 0.224 & & & -0.92 & 0.025 \\
\hline \multirow{6}{*}{ 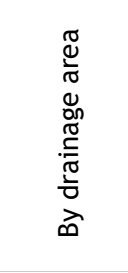 } & \multirow{2}{*}{$A_{1}$} & Rainfall & \multirow{2}{*}{0.96} & \multirow{2}{*}{0.002} & 0.97 & 0.001 & \multirow{2}{*}{0.68} & \multirow{2}{*}{0.105} & 0.70 & 0.119 \\
\hline & & Forest & & & -0.36 & 0.489 & & & -0.87 & 0.434 \\
\hline & \multirow{2}{*}{$\mathrm{A}_{2}$} & Rainfall & \multirow{2}{*}{0.93} & \multirow{2}{*}{0.006} & 0.96 & 0.002 & \multirow{2}{*}{0.69} & 0.099 & 0.79 & 0.060 \\
\hline & & Forest & & & -0.61 & 0.196 & & - & 0.37 & 0.470 \\
\hline & \multirow{2}{*}{$\mathrm{A}_{3}$} & Rainfall & \multirow{2}{*}{0.64} & \multirow{2}{*}{0.046} & 0.78 & 0.023 & O 72 & 0023 & 0.85 & 0.008 \\
\hline & & Forest & & & 0.32 & 0.435 & 0.12 & 0.025 & -0.16 & 0.712 \\
\hline & & Rainfall & 095 & 0003 & 0.96 & 0.003 & 0.54 & 0213 & -0.70 & 0.118 \\
\hline రั & $\mathrm{AP}_{1}$ & Forest & 0.93 & 0.003 & -0.30 & 0.562 & 0.34 & 0.213 & -0.21 & 0.677 \\
\hline$=0$ & $\Delta P_{2}$ & Rainfall & 059 & 0071 & 0.50 & 0.204 & 088 & בח00 & 0.94 & 0.001 \\
\hline. & $\mathrm{Ar}_{2}$ & Forest & 0.07 & 1 & 0.17 & 0.680 & 0.00 & 0.002 & -0.87 & 0.005 \\
\hline वे & $\Delta \mathrm{P}_{2}$ & Rainfall & 061 & 0152 & 0.73 & 0.098 & 072 & 077 & 0.82 & 0.044 \\
\hline & $\mathrm{AP}_{3}$ & Forest & 0.01 & 0.132 & -0.29 & 0.577 & 0.12 & 0.071 & -0.45 & 0.371 \\
\hline
\end{tabular}

were strongly influenced by rainfall and forest cover (Tab. 5). This allows to hypothesize that during the drought periods, minimum streamflows in this region (Pedro Canário, Baixo Guandú, Barra de São Gabriel, Ponte do Pancas, São Jorge, and Córrego da Piaba watersheds) are more sensitive to low rainfall due to the presence of forests.

According to Tucci \& Clarke (1997), of the amount of water that reaches the ground, the undrained part tends to infiltrate. Under these conditions, infiltration into forest soils is usually high, producing lower surface runoff. Besides, the increase in foliage surface area is closely related to the increase in rainfall interception and evapotranspiration rate. As a result, evapotranspiration is responsible for returning large volumes of water to the atmosphere, depending on the type of forest cover, stage, or density, and influencing the loss of soil moisture by the withdrawal of water from the plant roots.

A widely discussed hypothesis in the scientific community about the relationship between forests and streamflows is the "infiltration-evapotranspiration trade-off", postulated by Bruijnzeel $(1989,2004)$ and supported by other studies (Roa-García et al. 2011, Krishnaswamy et al. 2013, Ghimire et al. 2014). This hypothesis suggests that, as the forest cover is reduced, the water lost as streamflow due to reduced infiltration may outweigh the gains in the baseflow as evapotranspiration is reduced, which results in a decrease of watershed flows. On the other hand, since the infiltration capacity is conserved, the gains from reduced evapotranspiration may be higher, resulting in increased flows with reduced forest cover (Bruijnzeel 1989, 2004).

In this study, we observed higher streamflows in less forested areas and vice-versa. According to the land use survey that we used, approximately $49 \%$ of the Espírito Santo State land is composed of pastures, rocky outcrops, exposed soil, mining areas, and built-up areas. These land uses can reduce the infiltration capacity of soils compared to forest soils (Bruijnzeel 1989, 2004, Roa-García et al. 2011, Zabaleta et al. 2018, Peña-Arancibia et al. 2019). In addition, we found that about $20 \%$ of the state territory is occupied by crops and forest crops, both of which use machinery in the production cycle and can cause soil compaction. Finally, according to State Civil Defense (Governo do Estado do Espírito Santo 2020), the occurrence of hydrological disasters is usually common in the study area when the rainfall saturates the drainage capacity of soils and urban systems. This event occurs mainly because of the disordered urban occupation on slopes and river banks (Governo do Estado do Espírito Santo 2020), which should be ideally covered by vegetation.

The reduction in water infiltration into soil restricts the replenishment of groundwater (Bruijnzeel 2004). The "infiltrationevapotranspiration trade-off" hypothesis could explain a possible reduction in streamflows on less forested areas, which contrasts with the increases detected in our study. Thus, the negative relationship between forest and streamflow in addition to the stronger association found in drought periods is more related to gains attributed to the reduction in the evapotranspiration of the Atlantic Rainforest rather than to the improvement of the soil infiltration capacity.

Increases in streamflows due to decreased forest cover can be associated with water losses through forest evapotranspiration (Zhang et al. 2001). Annual evapotranspiration of areas with rare periods of water deficit in tropical forests, specifically in Brazil, can reach $70 \%$ of the incident rainfall (Bruijnzeel 1990). The various evapotranspiration rates of Brazilian forests (Dias et al. 2015, Bosquilia et al. 2018, Mello et al. 2019) provide material to understand water outflows to the atmosphere in watersheds with forest cover, as well as their impact on the volume of water that leaves the corresponding watercourses.

The negative association between forest cover and streamflows is likely a consequence of water consumption by vegetation. This event is significant during drought or low rainfall periods, and affects the water availability of watersheds under these circumstances. Regarding the negative relationship between forest cover and water availability, similar results were obtained in other studies under different methodologies and different vegetation types worldwide (Hornbeck et al. 1993, Roa-García et al. 2011, Brown et al. 2013, Mendes et al. 2018).

Regarding the difference between these results and the analysis of the 25 watersheds, besides the rainfall rate, we believe that this pattern is an effect of watersheds size, which may influence the hydrological 
response. Afterwards, the effect of the spatial scale on hydrological responses caused by changes in forest cover is still poorly understood and inconclusive. However, it is known that large and small watersheds can present different hydrological responses to the same factor analyzed (Zhang et al. 2017). Thus, the drainage area was tested as a criterion for watershed clustering.

Regression analysis carried out for the groups $A_{1}, A_{2}$, and $A_{3}$ showed that only rainfall significantly affected the streamflow, while the percentage of forest cover did not have a significant influence on streamflow (Tab. 4, Tab. 5). In this case, clustering of watersheds based on drainage area may have aggregated heterogeneous watershed in terms of rainfall amount and patterns, which could mask the effect of forest cover. Again, rainfall is a crucial factor for understanding streamflow dynamics. The large size of the watersheds (Tab. 1) can explain the strong influence of rainfall since there is less control of events and actions, with higher heterogeneity of environmental factors (Bruijnzeel 1990). As a result, as the watershed size increases, the effects of forest cover change in term of hydrological response is generally less pronounced (Zhang et al. 2017).

Our results showed that the percentage of forest cover had a significant influence on streamflow when the watershed groups based on drainage area and rainfall $\left(A P_{1}\right.$, $A P_{2}$, and $A P_{3}$ ) are considered. Besides, we found a significant influence of forest cover on the average streamflow ( $\mathrm{q}_{\text {ave }}$ ) for the $\mathrm{AP}_{2}$ group (varied sizes and lower rainfall) using a simple linear regression $\left(R^{2}=\right.$ 0.45 , $p$-value $=0.049-$ Tab. 4$)$. In the same group, the influence of forest cover on minimum streamflow $\left(q_{7}\right)$ was not significant $\left(R^{2}=0.03\right.$, $\mathrm{p}$-value $\left.=0.637\right)$, though it was significant by partial correlation $\left(r_{p}=\right.$. 0.87 , $\mathrm{p}$-value $=0.005$ ) using the rainfall as fixed effect.

The annual runoff is more sensitive to forest cover at different spatial scales in watersheds with limited rainfall, causing more significant hydrological responses (Zhang et al. 2017). In addition, the annual runoff also has an influence on water losses and affects the annual streamflows. As a result, our study shows that the lower rainfall rate found in the group $\mathrm{AP}_{2}$ was a driving factor for the occurrence of the significant relationship between minimum streamflows $\left(q_{7}\right)$ and forest cover. When the annual rainfall is lower, the minimum streamflow during drought periods may be more sensitive to rainfall as well as to the water demand of forests, which is probably higher in warmer and drier periods.

The effect of forests on flow patterns in the dry season is one of the most contradictory aspects in forest hydrology, with conflicting evidence for different combinations of forests, rainfall, and soil conditions. During the drought season, the effect of the balance between infiltration ca- pacity and evapotranspiration becomes even more prominent (Bruijnzeel 1989), which may explain the detection of a significant relationship between forest cover and minimum streamflow $\left(\mathrm{q}_{7}\right)$ in this study. We observed that all the significant partial correlation coefficients between streamflow and forest cover were negative, which means that smaller streamflows occurred in watersheds with a higher percentage of forest cover and vice-versa. We also observed the same tendency for most non-significant relationships. This is the opposite of the general belief that forests would increase the amount of water available in rivers. However, this is a controversial subject and our results may not be definitive about this topic.

Based on the dynamic of the balance between infiltration and evapotranspiration, we emphasize the importance of prioritizing good soil management practices among the land uses that already exist in watersheds. For example, reforestation of watersheds should be well planned considering the hydrological and soil conditions at each site. Indeed, the replacement of other land uses with forested areas may not always reflect substantial gains in streamflows (Ghimire et al. 2014). In some cases, soil surface conditions and the groundwater storage capacity can have a higher influence on water production during drought periods than deforestation or reforestation (Peña-Arancibia et al. 2019).

Although forests do not always increase the annual water yield in watersheds, it can affect other important hydrological mechanisms. For example, forest loss can weaken the regulating mechanisms of tropical watersheds, altering river flow regimes and possibly leading to extreme events, such as floods and/or water shortage (Salazar et al. 2018). Also, the quality of water resources and the environment in watersheds is positively affected by forest cover. Considering parameters such as soil structure, runoff control and flow variability over the seasons, sediment production, and water chemical properties (Anderson \& Lockaby 2011, Roa-García et al. 2011, Mello et al. 2018), a larger forest cover may ensure a safer and more reliable water supply for local population (Krishnaswamy et al. 2013).

Large-scale deforestation in tropical rainforests can influence the tropospheric moisture flows and atmospheric processes that regulate the transition between dry and rainy seasons. According to observations of reciprocal feedbacks on climateforest for the Amazon, deforestation can delay the onset of rainfall at regional scale, as discussed by Chambers \& Artaxo (2017), Laurance \& Williamson (2001), and Wright et al. (2017). Further analysis of the influences of vegetation evapotranspiration on the beginning of the rainy season in the Brazilian Atlantic Rainforest is necessary to generalize this process.

\section{Conclusions}

Water security for human society is a real need and a worldwide concern. On the other hand, population growth and the development of productive activities are closely related to land-use changes and the conversion of forest areas.

In this study, we analyzed the relationships between streamflow, rainfall and forest cover over the period 2007/2008 in the Espirito Santo State, southeastern Brazil, by grouping watersheds with similar physical and/or environmental characteristics. This approach can help local managers to better understand how forest management can reduce or increase hydrological availability.

The average minimum streamflow during seven days $\left(q_{7}\right)$ was more sensitive to the presence of forest cover, showing a negative relationship, especially in watersheds with low annual rainfall. Regarding the areas with high rainfall levels, the annual rainfall showed a strong influence on the hydrological responses of watersheds, regardless of the percentage of forest cover.

The methodology applied in this study is a viable and easy-to-apply alternative to (but not a substitute of) consolidated methods in hydrological science, such as experimental watersheds and long-term time-trends. Our approach can be usefully replicated in other regions, as long as the hydrological variables for the analyzed period fall within their normal historical range, since it does not require the experimental suppression of forest cover and allows the simultaneous study of several watersheds, which can be very useful for water management. Moreover, other environmental variables related to the hydrological dynamics of watersheds may be included in the analysis, aimed to throw light in greater detail on this complex association.

\section{Acknowledgements}

We thank the National Council for Scientific and Technological Development (CNPq) for the financial support of this study.

\section{References}

Alvares CA, Stape JL, Sentelhas PC, Gonçalves JLM, Sparovek G (2013). Köppen's climate classification map for Brazil. Meteorologische Zeitschrift 22: 711-728. - doi: 10.1127/0941-2948/2013/ 0507

ANA (2017). Conjuntura dos recursos hídricos no Brasil: relatório pleno [Water resources situation in Brazil: full report]. ANA, Brasilia, Brazil, pp. 169. [in Portuguese] [online] URL: http:// www.snirh.gov.br/portal/snirh/centrais-de-con teudos/conjuntura-dos-recursos-hidricos/relato rio-conjuntura-2017.pdf/view

Anderson CJ, Lockaby BG (2011). The effectiveness of forestry best management practices for sediment control in the Southeastern United States: a literature review. Southern Journal of Applied Forestry 35: 170-177. - doi: 10.1093/sjaf/ 35.4.170

Andréassian V (2004). Waters and forests: from 
historical controversy to scientific debate. Journal of Hydrology 291: 1-27. - doi: 10.1016/j.jhydr ol.2003.12.015

Awange JL, Mpelasoka F, Goncalves RM (2016). When every drop counts: analysis of droughts in Brazil for the 1901-2013 period. Science of the Total Environment 566-567 (7): 1472-1488. - doi: 10.1016/j.scitotenv.2016.06.031

Awotwi A, Anournu GK, Quaye-Ballard JA, Anoor T, Forkuo EK, Harris E, Agyekum J, Terlabie JL (2019). Water balance responses to land-use/ land-cover changes in the Pra River Basin of Ghana, 1986-2025. Catena 182: 1-13. - doi: 10.1016 /j.catena.2019.104129

Bosquilia RWD, Neale CMU, Duarte SN, Longhi SJ, Ferraz SFB, Muller-Karger FE, McCarthy MJ (2018). Evaluation of evapotranspiration variations as a function of relief and terrain expo sure through multivariate statistical analysis. Ecohydrology and Hydrobiology 19: 307-315. doi: 10.1016/j.ecohyd.2018.11.001

Brown AE, Zhang L, McMahon TA, Western AW, Vertessy RA (2005). A review of paired catchment studies for determining changes in water yield resulting from alterations in vegetation. Journal of Hydrology 310: 28-61. - doi: 10.1016/j. hydrol.2004.12.010

Brown AE, Western AW, McMahon TA, Zhang L (2013). Impact of forest cover changes on annual streamflow and flow duration curves. Journal of Hydrology 483: 39-50. - doi: 10.1016/j. jhydrol.2012.12.031

Bruijnzeel LA (1989). (De)forestation and dry season flow in the tropics: a closer look. Journal of Tropical Forest Science 1: 229-243. [online] URL: http://www.jstor.org/stable/435945 78

Bruijnzeel LA (1990). Hydrology of moist tropical forests and effects of conversion: a state of knowledge review. UNESCO International Hydrological Programme, Paris, France, pp. 230. [online] URL: http://www.cabdirect.org/cabdir ect/abstract/19930664882

Bruijnzeel LA (2004). Hydrological functions of tropical forests: not seeing the soil for the trees? Agriculture, Ecosystems and Environment 104: 185-228. - doi: 10.1016/j.agee.2004.01. 015

Chambers JQ, Artaxo P (2017). Biosphere-atmosphere interactions: deforestation size influences rainfall. Nature Climate Change 7: 175 176. - doi: 10.1038/nclimate3238

Chaves LCG, Lopes FB, Maia ARS, Meireles ACM, Andrade EM (2019). Water quality and anthropogenic impact in the watersheds of service reservoirs in the Brazilian semi-arid region. Re vista Ciência Agronômica 50: 223-233. [online] URL: http://www.scielo.br/j/rca/a/7zK3pkycrgvG SLNFL58cDgj/?format=pdf\&lang=en

Cheng B, Li H, Yue S, Huang K (2019). A conceptual decision-making for the ecological base flow of rivers considering the economic value of ecosystem services of rivers in water short age area of Northwest China. Journal of Hydrology 578: 1-7. - doi: 10.1016/j.jhydrol.2019.05. 020

Cunha AP, Marengo JA, Alvala RC, Deusdara-Leal KR, Cuartas LA, Seluchi M, Zeri M, Ribeiro-Neto G, Brodel E, Cunningham C, Costa L, Moraes OLL (2019). Secas e seus impactos no Brasil em 2018 [Droughts and their impacts in Brazil in
2018]. CEMADEN, São José dos Campos, SP, Brazil, pp. 19. [in Portuguese] [online] URL: http://www.cemaden.gov.br/secas-e-seus-imp actos-no-brasil-em-2018/

Dias LCP, Macedo MN, Costa MH, Coe MT, Neill C (2015). Effects of land cover change on evapotranspiration and streamflow of small catchments in the Upper Xingu River Basin, Central Brazil. Journal of Hydrology: Regional Studies 4: 108-122. - doi: 10.1016/j.ejrh.2015.05.010 Ferreira VG, Montecino HC, Ndehedehe CE, Heck B, Gong Z, Freitas SRC, Westerhaus M (2018). Space-based observations of crustal deflections for drought characterization in Brazil. Science of the Total Environment 644: 256-273. doi: 10.1016/j.scitotenv.2018.06.277

Ghimire CP, Bruijnzeel LA, Lubczynski MW, Bonell M (2014). Negative trade-off between changes in vegetation water use and infiltration recovery after reforesting degraded pasture land in the Nepalese Lesser Himalaya. Hydrology and Earth System Sciences 18: 49334949. - doi: 10.5194/hess-18-4933-2014

Giri S, Arbab NN, Lathop RG (2018). Water security assessment of current and future scenarios through an integrated modeling framework in the Neshanic River watershed. Journal of Hydrology 563: 1025-1041. - doi: 10.1016/j.jhydrol.20 18.05.046

Governo do Estado do Espírito Santo (2020). PEPDEC - Plano estadual de proteção e defesa civil do Espírito Santo [PEPDEC - State plan for protection and civil defense of Espírito Santo]. Vitória, ES, Brazil, pp. 71. [in Portuguese] [online] URL: https://defesacivil.es.gov.br/publicac oes-2

Guzha AC, Rufino MC, Okoth S, Jacobs S, Nobrega RLB (2018). Impacts of land use and land cover change on surface runoff, discharge and low flows: evidence from East Africa. Journal of Hydrology: Regional Studies 15: 49-67. - doi: 10.1016/j.ejrh.2017.11.005

Hellweger F (1997). AGREE - DEM surface reconditioning system. Web site. [online] URL: http:// www.ce.utexas.edu/prof/maidment/gishydro/f erdi/research/agree/agree.html

Hewlett JD, Lull HW, Reinhart KG (1969). In defense of experimental watersheds. Water Resources Research 5: 306-316. - doi: 10.1029/WRo 05 ioo1poozo6

Hornbeck JW, Adams MB, Cobett ES, Verry ES, Lynch A (1993). Long-term impacts of forest treatments on water yield: a summary for northeastern USA. Journal of Hydrology 150: 323-344. - doi: 10.1016/0022-1694(93)90115-P Krishnaswamy J, Bonell M, Venkatesh B, Purandara BK, Rakesh KN, Lele S, Kiran MC, Reddy V, Badiger $S$ (2013). The groundwater recharge response and hydrologic services of tropical humid forest ecosystems to use and reforestation: support for the "infiltration-evapotranspiration trade-off hypothesis". Journal of Hydrology 498: 191-209. - doi: 10.1016/j.jhydrol.2013.06. 034

Laurance WF, Williamson GB (2001). Positive feedbacks among forest fragmentation, drought, and climate change in the Amazon. Conservation Biology 15: 1529-1535. - doi: 10.1046/j.1523-1739.2001.01093.x

Lawrence D, Vandecar K (2015). Effects of tropical deforestation on climate and agriculture.
Nature Climate Change 5: 27-36. - doi: 10.1038/ nclimate2430

Mello CR, Avila LF, Lin H, Terra MCNS, Chappell NA (2019). Water balance in a neotropical forest catchment of southeastern Brazil. Catena 173: 9-21. - doi: 10.1016/j.catena.2018.09.046

Mello K, Valente RA, Randhir TO, Vettorazzi A (2018). Impacts of tropical forest cover on water quality in agricultural watersheds in southeastern Brazil. Ecological Indicators 93: 12931301. - doi: 10.1016/j.ecolind.2018.06.030

Mendes NGS, Cecílio RA, Zanetti SS (2018). Forest coverage and streamflow of watersheds in the tropical Atlantica rainforest. Revista Arvore 42: 2-10. - doi: 10.1590/1806-908820180002000 04

Neary D (2016). Long-term forest paired catchment studies: what do they tell us that landscape-level monitoring does not? Forests 7: 115. - doi: 10.3390/f7080164

Nikolic G, Spalevic V, Curovic M, Khaledi Darvishan A, Skataric G, Pajic M, Kavian A, Tanaskovik $\checkmark$ (2019). Variability of soil erosion intensity due to vegetation cover changes: case study of Orahovacka Rijeka, Montenegro. Notulae Botanicae Horti Agrobotanici Cluj-Napoca 47: 237-248. - doi: $10.15835 /$ nbha47111310

Peña-Arancibia JL, Bruijnzeel LA, Mulligan $M$, Van Dijk AIJM (2019). Forests as "sponges" and "pumps": assessing the impact of deforestation on dry-season flows across the tropics. Journal of Hydrology 574: 946-963. - doi: 10.101 6/j.jhydrol.2019.04.064

Roa-García MC, Brown S, Schreier H, Lavkulich LM (2011). The role of land use and soils in regulating water flow in small headwater catchments of the Andes. Water Resources Research 47: 1-12. - doi: 10.1029/2010WRoo9138

Sadeghi SH, Hazbavi Z, Gholamalifard M (2019). Interactive impacts of climatic, hydrologic and anthropogenic activities on watershed health. Science of the Total Environment 648: 880-893. - doi: 10.1016/j.scitotenv.2018.08.004

Salazar JF, Villegas JC, Rendón AM, Rodríguez E (2018). Scaling properties reveal regulation of river flows in the Amazon through a "forest reservoir". Hydrology and Earth System Sciences 22: 1735-1748. - doi: 10.5194/hess-22-17352018

Santos EHM, Griebeler NP, Oliveira LFC (2010). Relação entre o uso do solo e comportamento hidrológico na Bacia Hidrográfica do Ribeirão João Leite [Relationship between land use and hydrologic behavior in the Ribeirão João Leite Basin]. Revista Brasileira de Engenharia Agrícola e Ambiental 14: 826-834. [in Portuguese] doi: $10.1590 /$ S1415-43662010000800006

Schenk ER, O'Donnel F, Springer AE, Stevens LE (2020). The impacts of tree stand thinning on groundwater recharge in aridland Forests. Ecological Engineering 145: 1-11. - doi: 10.1016/j.eco leng.2019.105701

Shiklomanov IA (1993). World fresh water resources. In: "Water in Crisis: a Guide to the World's Fresh Water Resources" (Gleick PH ed). Oxford University Press, Oxford, UK, pp. 13-24.

Silva KR, Cecílio RA, Xavier AC, Pezzopane JRM, Garcia GO (2011). Interpolação espacial da precipitação no estado do Espírito Santo [Spatial interpolation of precipitation in Espírito Santo 
state]. Floresta e Ambiente 18: 417-427. [in Portuguese] - doi: 10.4322/floram.2011.061

Tucci CEM, Clarke RT (1997). Impacto das mudanças da cobertura vegetal no escoamento: revisão [Impact of vegetation cover changes on outflow: review]. Revista Brasileira de Recursos Hídricos 2: 135-152. [in Portuguese] - doi: 10.21168/rbrh.v2n1.p135-152

Tu M, Hall MJ, De Laat PJM, De Wit MJM (2004). Detection of long-term changes in precipitation and discharge in the Meuse basin. GIS and Remote Sensing in Hydrology, Water Resouces and Environment. IAHS Publications 289: 169177.

Wang H, Asefa T, Bracciano D, Adams A, Wanakule N (2019). Proactive water shortage mitigation integrating system optimization and input uncertainty. Journal of Hydrology 571: 711-722. doi: 10.1016/j.jhydrol.2019.01.071

Ward H Jr (1963). Hierarchical grouping to optimize an objective function. Source Journal of the American Statistical Association 58: 236244. - doi: 10.1080/01621459.1963.10500845

Wright JS, Fu R, Worden JR, Chakraborty S, Clinton NE, Risi C, Sun Y, Yin L (2017). Rainforest-initiated wet season onset over the southern Amazon. Proceedings of the National Academy of Sciences USA 114: 8481-8486. - doi: 10.1073/ pnas.1621516114

Xavier AC, King CW, Scanlon BR (2016). Daily gridded meteorological variables in Brazil (1980-2013). International Journal of Climatology 36: 2644-2659. - doi: 10.1002/joc.4518

Zabaleta A, Garmendia E, Mariel P, Tamayo I, An- tiguedad I (2018). Land cover effects on hydrologic services under a precipitation gradient. Hydrology and Earth System Sciences 22: 52275241. - doi: 10.5194/hess-22-5227-2018

Zhang L, Dawes W, Walker G (2001). Response of mean annual evapotranspiration to vegetation changes at catchment scale. Water Resources Research 37: 701-708. - doi: 10.1029/2000WR90 0325

Zhang M, Liu N, Harper R, Li Q, Liu K, Wei X, Ning D, Hou Y, Liu $S$ (2017). A global review on hydrological responses to forest change across multiple spatial scales: importance of scale, climate, forest type and hydrological regime. Journal of Hydrology 546: 44-59. - doi: 10.1016/j. jhydrol.2016.12.040 